\title{
Microevolutionary relationships between biotypes of Elymus confusus, E. peschkovae, and $E$. sibiricus (Poaceae) according to hybridization and sequencing of the nuclear gene GBSS1 (waxy)
}

\author{
Alexander $V$. Agafonov ${ }^{*}$, Maria $V$. Emtseva, and Elena $V$. Shabanova (Kobozeva) \\ Central Siberian Botanical Garden SB RAS, 630090 Novosibirsk, Russia
}

\begin{abstract}
According to descriptions, the Siberian species E. peschkovae and $\boldsymbol{E}$. confusus differ in the presence or absence of trichomes on lemma and rachilla surfaces only. Two methods were used for study microevolutionary relationships between these species: hybridization of biotypes from different locations and analysis of nucleotide sequences of the low-copy nuclear gene GBSS1. Created and grown hybrids in combinations AMU-8804 $\times$ BER-0807 and AMU-8804 $\times$ BUK-1109 showed complete seed sterility in two field vegetations. Taking into account wide species areas, 3 hybrids were created between Magadan biotypes from a common habitat in the combination $\boldsymbol{E}$. confusus MOL$1887 \times$ E. peschkovae MOL-1882. The plants showed seed fertility (SF) of $0-3 \%$. This result does not obscure the possibility to assess SF in the $\mathrm{F}_{2}$ generation and the character of inheritance of diagnostic traits. A comparative study of the GBSS1 gene sequences in accessions was carried out in comparison with clones of reference species. Differentiation of clones by the $\mathbf{S t}_{2}$ subgenome in $E$. confusus, E. peschkovae, E. sibiricus and $\boldsymbol{E}$. caninus did not reveal a clear relationships between the species. Meanwhile, a certain species specificity for the $\mathbf{H}_{\mathbf{1}}$ subgenome was noted, confirming the existence of microevolutionary isolation of these species.
\end{abstract}

\section{Introduction}

Elymus sibiricus L. and E. confusus (Roshev.) Tzvel. are spreaded everywhere in southern regions of Siberia [1]. In the Russian Far East $\boldsymbol{E}$. confusus area is shifted to the North, where it totally replaces $\boldsymbol{E}$. sibiricus [2]. Both species are characterized by glabrous lemmas, but $\boldsymbol{E}$. sibiricus rarely have shortly pilous lemmas. It was shown in the previous experiment that interspecific introgression is possible under the joint growth of these two species in Siberia, as a result of sexual hybridization [3].

* Corresponding author: agalex@mail.ru 
Created and analyzed hybrids of East-Sajan biotypes in combination $\boldsymbol{E}$. sibiricus BUR$0569 \times \boldsymbol{E}$. confusus BUM-0505 in generation $\mathbf{F}_{1}$ showed mostly opened anthers, values of seed fertility (SF) accounted for 2-7 seeds per spike.

Among 20 plants of the $\mathbf{F}_{\mathbf{2}}$ generation, grown on the opened plot, 17 corresponded to E. sibiricus on the trait of doubled spikelets on spike ledge, 3 plants carried single spikelets on all spikes. These results gave reason to refer $\boldsymbol{E}$. sibiricus and $\boldsymbol{E}$. confusus to a unified recombination gene pool with reproductive compatibility at the $\alpha 2$ level at least within the Southern Siberia area.

Elymus peschkovae Tzvelev (- Agropyron confusum var. pubiflorum Roshev. Elymus confusus var. pubiflorus (Roschev.) Tzvelev - E. pubiflorus (Roshev.) Peschkova) differs from E. confusus by pilose lemmas (Fig. 1). In Siberia the area of E. peschkovae is distinctly shifted to the North-East part in comparison with $\boldsymbol{E}$. confusus.

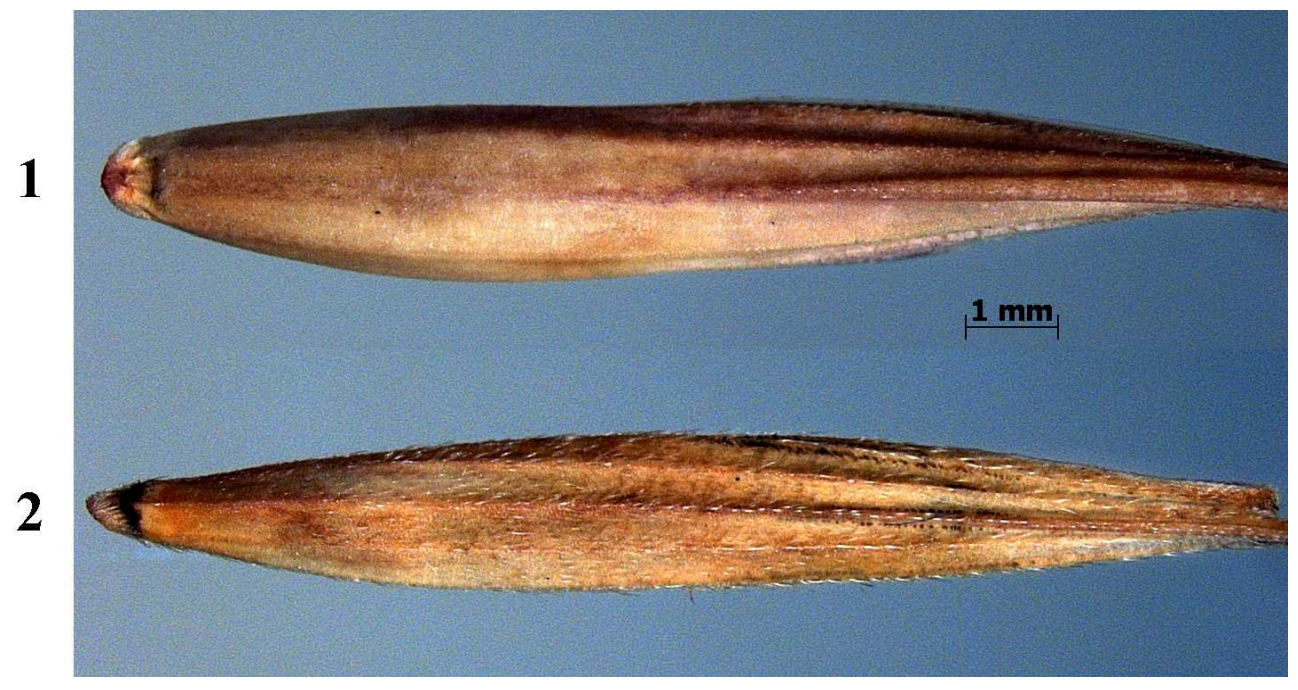

Fig. 1. Seeds (lemmas) of accessions E. confusus MOL-1887 (1) and E. peschkovae MOL-1882 (2)

The purpose of this research was to study microevolutionary relationships between E. peschkovae and E. confusus biotypes. Two experimental methods were used: hybridization of biotypes from different points of species area, and analysis of nucleotide sequences of low-copy nuclear gene waxy (granule-bound starch synthase 1, GBSS1).

\section{Materials and Methods}

Parental biotypes for hybridization were grown from seeds of wild-growing accessions collected at different points of areas, or from seeds of their offspring grown under conditions of self-pollination. Plants were hybridized according to the previously developed technique [4]. Techniques of probe preparation and sequences study of the GBSS1 gene in three species were performed as described earlier [5]. The origin of accessions and clone numbers submitted to the GenBank NCBI (http://www.ncbi.nlm.nih.gov/nuccore) are shown in Table 1. In addition to accessions of three species and monogenomic markers, clones of $\boldsymbol{E}$. caninus (L.) L. from GenBank NCBI, as a morphologically related species, were included in the study of GBSS1 sequences (Table 2). The construction of dendrograms by the Neighbor-Joining method was carried out in the TREECON ver. $1.3 b$ soft [6]. 
Table 1. Accessions and clones of GBSS1 gene sequences in E. confusus, E. peschkovae, E. sibiricus which have been submitted to the GenBank NCBI.

Accessions taken for hybridization are marked by bold

\begin{tabular}{|c|c|c|}
\hline Accession & Clones (sequences) in NCBI & Location of collecting \\
\hline \multicolumn{3}{|c|}{ E. confusus } \\
\hline TAR-0730 & $\begin{array}{l}\text { conTAR30_1-St MN164827 } \\
\text { conTAR30_4-H MN164828 }\end{array}$ & $\begin{array}{l}\text { The Tyva Republic, Tes- } \\
\text { Khemsky District, alt. } 1545 \text { м N } \\
50^{\circ} 36.870^{\prime} \text { E } 95^{\circ} 10.729^{\prime}\end{array}$ \\
\hline BER-0807 & $\begin{array}{l}\text { conBER07_2-St MN164825 } \\
\text { conBER07_1-H MN164826 }\end{array}$ & $\begin{array}{l}\text { The Republic of Buryatia, } \\
\text { Eravnensky District, alt. } 958 \text { м N } \\
53^{\circ} 00.776 \text { ' E } 112^{\circ} 03.673^{\prime}\end{array}$ \\
\hline BUR-0557 & $\begin{array}{l}\text { conBUR57_7-St MZ605026 } \\
\text { conBUR576a-H MZ605025 }\end{array}$ & $\begin{array}{l}\text { The Republic of Buryatia, } \\
\text { Okinsky District, alt. } 1858 \text { м N } \\
51^{\circ} 57.383^{\prime} \text { E } 100^{\circ} 33.564{ }^{\prime}\end{array}$ \\
\hline BUM-0505 & $\begin{array}{l}\text { conBUM05_1-St MZ605028 } \\
\text { conBUM05_7-H MZ605027 }\end{array}$ & $\begin{array}{l}\text { The Republic of Buryatia, } \\
\text { Tunkinsky District, alt. } 1738 \text { м N } \\
51^{\circ} 42.610^{\prime} \text { ' E } 100^{\circ} 59.967\end{array}$ \\
\hline BUK-1109 & $\begin{array}{l}\text { conBUK09_8-St MZ605030 } \\
\text { conBUK09_6-H MZ605029 }\end{array}$ & $\begin{array}{l}\text { The Republic of Buryatia, } \\
\text { Eravnensky District, alt. } 750 \mathrm{M} \mathrm{N} \\
50^{\circ} 32.762^{\prime} \text { E } 107^{\circ} 47.435^{\prime}\end{array}$ \\
\hline MOL-1887 & conMOL87_2-H MZ605031 & $\begin{array}{l}\text { Magadan Region, Olsky District, } \\
\text { alt. } 6 \text { м N } 59^{\circ} 34.913^{\prime} \text { E } 151^{\circ} \\
16.585^{\prime}\end{array}$ \\
\hline MOK-1895 & $\begin{array}{l}\text { conMOK95_3-St MZ605033 } \\
\text { conMOK95_4-H MZ605032 }\end{array}$ & $\begin{array}{l}\text { Magadan Region, Olsky } \\
\text { District,alt. } 24 \text { м N } 59^{\circ} 36.706^{\prime} \text { E } \\
150^{\circ} 27.629^{\prime}\end{array}$ \\
\hline \multicolumn{3}{|c|}{ E. peschkovae } \\
\hline AMU-8804 & $\begin{array}{l}\text { pesAMU04_3-St MN164829 } \\
\text { pesAMU04_1-H MN164830 }\end{array}$ & $\begin{array}{l}\text { Amur region, Tyndinsky District, } \\
\text { alt. } 441 \mathrm{~m} \mathrm{~N} 54^{\circ} 56.216^{\prime} \text { E } 125^{\circ} \\
21.854^{\prime}\end{array}$ \\
\hline MJA-1106 & $\begin{array}{l}\text { pesMJA06_3-St MN164831 } \\
\text { pesMJA06_2-H MN164832 }\end{array}$ & $\begin{array}{l}\text { Magadan Region, Khasynsky } \\
\text { district, alt. } 755 \text { м N } 60^{\circ} 19.467 \\
\text { E } 151^{\circ} 10.540^{\prime}\end{array}$ \\
\hline MOL-1882 & $\begin{array}{l}\text { pesMOL82_1-St MZ634450 } \\
\text { pesMOL82_7-H MZ634449 }\end{array}$ & $\begin{array}{l}\text { Magadan Region, Olsky District, } \\
\text { alt. } 6 \text { м N } 59^{\circ} 34.913 \text { ' E } 151^{\circ} \\
16.585^{\prime}\end{array}$ \\
\hline JTO-1708 & $\begin{array}{l}\text { pesJTO08_2-St MZ605035 } \\
\text { pesJTO08_3-H MZ605034 }\end{array}$ & $\begin{array}{l}\text { The Sakha (Yakutia) Republic, } \\
\text { Oymyakonsky District, alt. } 810 \mathrm{M} \\
\text { N } 63^{\circ} 20.705^{\prime} \text { E } 141^{\circ} 48.050^{\prime}\end{array}$ \\
\hline \multicolumn{3}{|c|}{ E. sibiricus } \\
\hline JAC-1504 & $\begin{array}{l}\text { sibJAC04_1-St MN164833 } \\
\text { sibJAC04_2-H MN164834 }\end{array}$ & $\begin{array}{l}\text { The Sakha (Yakutia) Republic, } \\
\text { vicinity of Yakutsk town }\end{array}$ \\
\hline MOK-1896 & $\begin{array}{l}\text { sibMOK96_3-H MZ634451 } \\
\text { sibMOK96_4-H MZ634452 }\end{array}$ & $\begin{array}{l}\text { Magadan Region, Olsky District, } \\
\text { alt. } 24 \text { м N } 59^{\circ} 36.706^{\prime} \text { E } 150^{\circ} \\
27.629^{\prime}\end{array}$ \\
\hline
\end{tabular}

Table 2. Species accessions and their clones drawn from the GenBank NCBI.

\begin{tabular}{|l|l|c|c|}
\hline Species & Accession (origin) & $\begin{array}{l}\text { Sequence in } \\
\text { NCBI }\end{array}$ & $\begin{array}{l}\text { Designation on } \\
\text { dendrograms }\end{array}$ \\
\hline Elymus sibiricus & PI 628699, Russia & $\begin{array}{l}\text { St HM035280 } \\
\text { H HM035281 }\end{array}$ & $\begin{array}{l}\text { sib_5280_S } \\
\text { sib_5281_H }\end{array}$ \\
\hline E. sibiricus & PI 499461, China & $\begin{array}{l}\text { St HM035282 } \\
\text { H HM035283 }\end{array}$ & sib_5282_S \\
& & sib_5283_H \\
\hline E. caninus & ABZ-1654, Russia & St MN164839 & canABZ54_2 \\
& & H MN164840 & canABZ54_1 \\
\hline
\end{tabular}




\begin{tabular}{|c|c|c|c|}
\hline E. caninus & $\begin{array}{l}\text { PI } 314612 \\
\text { Kazakhstan }\end{array}$ & $\begin{array}{c}\text { St b-HM035270 } \\
\text { H a-HM035271 }\end{array}$ & $\begin{array}{l}\text { can_5270_S } \\
\text { can_5271_H }\end{array}$ \\
\hline E. caninus & PI 499413 China & $\begin{array}{l}\text { St a-HM035272 } \\
\text { H b-HM035273 }\end{array}$ & $\begin{array}{l}\text { can_5272_S } \\
\text { can_5273_H }\end{array}$ \\
\hline E. caninus & PI 531571 Poland & $\begin{array}{l}\text { St a-HM035274 } \\
\text { H b-HM035275 }\end{array}$ & $\begin{array}{l}\text { can_5274_S } \\
\text { can_5275_H }\end{array}$ \\
\hline $\begin{array}{l}\text { E. gmelinii } \\
\text { (Ledeb.) } \\
\text { Tzvelev }\end{array}$ & PI 499447 China & $\begin{array}{l}\text { St GQ847726 } \\
\text { Y GQ847727 }\end{array}$ & $\begin{array}{l}\text { gme_7726_S } \\
\text { gme_7727_Y }\end{array}$ \\
\hline $\begin{array}{l}\text { E. pendulinus } \\
\text { (Nevski) } \\
\text { Tzvelev }\end{array}$ & PI 499452 China & $\begin{array}{l}\text { St GQ847731 } \\
\text { Y GQ847732 }\end{array}$ & $\begin{array}{l}\text { pen_7731_S } \\
\text { pen_7732_Y }\end{array}$ \\
\hline $\begin{array}{l}\text { Pseudoroegneri } \\
\text { a strigosa } \\
\text { (M.Bieb.) A. } \\
\text { Löve }\end{array}$ & PI 499637 China & St EU282323 & P.str_323 \\
\hline P. strigosa & PI 531755 China & St AY360823 & P.str_823 \\
\hline $\begin{array}{l}\text { P. spicata } \\
\text { (Pursh) A. Löve }\end{array}$ & PI 232117 USA & St AF079281 & P.spi_281 \\
\hline P. spicata & PI 610986 USA & St AY010999 & P.spi_999 \\
\hline $\begin{array}{l}\text { Hordeum } \\
\text { jubatum } \mathrm{L} .\end{array}$ & RJMG 106 USA & H AY010963 & H.jub_63_H \\
\hline $\begin{array}{l}\text { H. californicum } \\
\text { Covas \& } \\
\text { Stebbins }\end{array}$ & MA-138-1-4 USA & AF079273 & H.cal_73_H \\
\hline $\begin{array}{l}\text { Bromus } \\
\text { tectorum } \mathrm{L} .\end{array}$ & - & AY362757 & Bromus_AY3 \\
\hline
\end{tabular}

\section{Results and Discussions}

Hybrids between E. peschkovae (Amur region) and E. confusus (The Republic of Buryatia), created and grown by us in combinations AMU-8804 $\times$ BER-0807 (2 plants) and AMU-8804 $\times$ BUK-1109 ( 2 plants), have shown total seed sterility. This phenomenon forced us to return to the problem of phylogenetical relationships between three species, especially considering their wide distribution areas within the Asian part of Russia.

In vegetation period 2020 we have created 3 hybrids between Magadan biotypes from the common ecotope in the valley of river Ola in combination $\boldsymbol{E}$. confusus MOL-1887 $\times$ E. peschkovae MOL-1882. In the greenbox all three plants had a little part of opened anthers and showed low fertility (SF) $0-3 \%$, which was confirmed on the open experimental plot. This result does not obscure the possibility to estimate inheritance of the distinctive (diagnostic) traits and dynamics of SF in the $\mathbf{F}_{2}$ generation.

At the same time we carried out a comparative research of the GBSS1 gene sequences in collection accessions $\boldsymbol{E}$. peschkovae and E. confusus from the different points of area compared to clones of reference species. Dendrogram, built on the data of GBSS1 gene sequences (exons from 9 to 14 only), is shown on the Fig. 2.

Based on these results, the following conclusions were made:

1. The StH-genomic constitution was confirmed for E. confusus, E. peschkovae and E. sibiricus.

2. All gene variants of St subgenome in studied species are phylogenetically close to the North American ancestral line $\mathbf{S t}_{\mathbf{2}}$ of Pseudoroegneria genus, unlike the $\mathbf{S t}$ subgenome of reference Asian $\mathrm{StY}$-genomic species $\boldsymbol{E}$. pendulinus and $\boldsymbol{E}$. gmelinii. The group of $\mathbf{S t}_{2}$ clones of Siberian $\boldsymbol{E}$. confusus accessions separated from the larger group of $\boldsymbol{E}$. confusus, E. peschkovae and $\boldsymbol{E}$. sibiricus species with the bootstrap support value 87. 
3. As for the $\mathrm{H}$ subgenome, all studied species showed relation only within the Asian group $\mathbf{H}_{1}$, which is phylogenetically close to $\boldsymbol{H}$. jubatum. Wherein all $\boldsymbol{E}$. caninus clones separated from other species with the bootstrap support value 58.

4. Three of the four E. peschkovae clones belonging to the $\mathrm{H}$ subgenome were separated from the $\boldsymbol{E}$. confusus clones into a particular clade, which is probably not an accidental event and supports the microevolutionary isolation of the two species. We can suppose an independent origination of the trait «pilose lemmas» in the mountane biotype E. peschkovae JTO-1708, which is located in the other separated branch E. confusus E. sibiricus.

5. The largest group of $\mathbf{H}_{1}$ subgenome comprised all $\boldsymbol{E}$. sibiricus clones except the one from Yakutia-Sakha, and four $\boldsymbol{E}$. confusus clones. This fact can hypothetically explain the high reproductive compatibility of the $\boldsymbol{E}$. confusus BUM-0505 accession when hybridized with the accession $\boldsymbol{E}$. sibiricus BUR-0569 from Buryatia (Agafonov, Gerus, 2009).

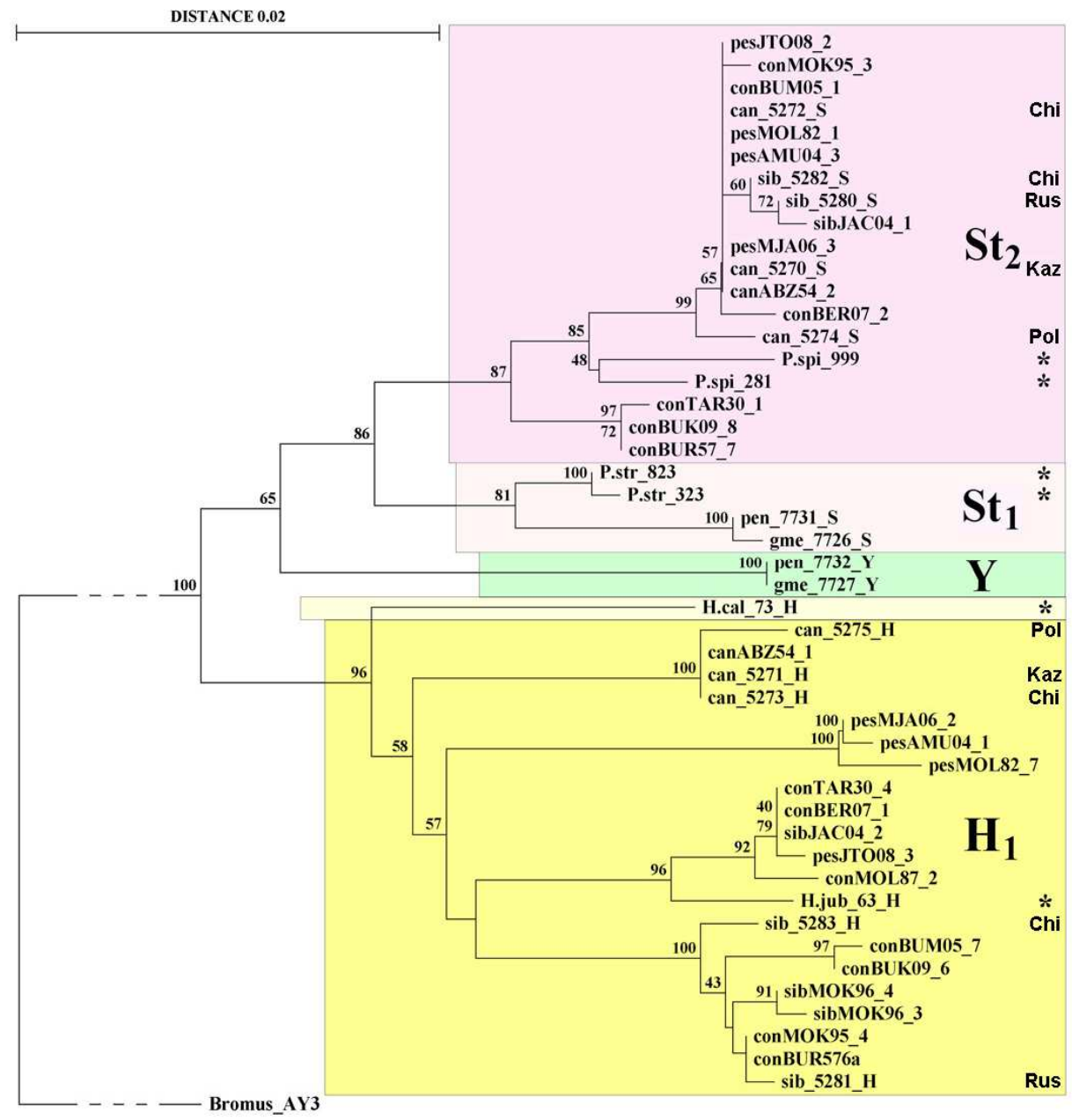

Fig. 2. NJ dendrogram, based on the results of analysis of GBSS1 gene sequences (only exons 9-14) in accessions $\boldsymbol{E}$. confusus, $\boldsymbol{E}$. peschkovae, $\boldsymbol{E}$. sibiricus compared to reference species from the GenBank NCBI. Monogenomic species that carry subgenomes St and H are marked by asterisks.

This work was performed in the scope of state assignment for CSBG SB RAS «Estimation of the morphogenetic potential of the North Asian plant population by experimental 
methods» (state registration number: AAAA-A17-117012610051-5). The materials of the bio-resource scientific collections of the CSBG SB RAS USU № 440534 and USU № 440537 (NS, NSK) were used. DNA sequencing was performed in Genomics Core Facility (ICBFM SB RAS, Novosibirsk).

\section{References}

1. G. A. Peschkova, Flora of Siberia, 2 (1990)

2. N. N. Tzvelev, N. S. Probatova, Grasses of Russia, (KMK Scientific Press, Moscow, 2019)

3. A. V. Agafonov, D. E. Gerus, The Plant World of Asiatic Russia, 2, 4 (2009) (In Russian)

4. A. V. Agafonov, Rus. J. Genetics, 40, 11 (2004)

5. A. V. Agafonov, S. V. Asbaganov, E. V. Shabanova (Kobozeva), I. V. Morozov, A. A. Bondar, Vavilov Journal of Genetics and Breeding, 23, 7 (2019)

6. Y. Van de Peer, R. De Wachter, Comp. Appl. Biosci., 10, 5 (1994) 